Doi: HTTPS://DOI.ORG/10.23910/2/2020.0368

\title{
Micropropagation of Medicinal Plants: a Review
}

\author{
Tuhin Chatterjee and Biswajit Ghosh*
}

Plant Biotechnology Lab, Post Graduate Department of Botany, Ramakrishna Mission Vivekananda Centenary College, Rahara, Kolkata, West Bengal (700 118), India

\section{Corresponding Author}

Biswajit Ghosh

e-mail: ghosh_b2000@yahoo.co.in

\author{
Article History \\ Article ID: IJEP0368 \\ Received in $19^{\text {th }}$ March, 2020 \\ Received in revised form $04^{\text {th }}$ April, 2020 \\ Accepted in final form $13^{\text {th }}$ April, 2020
}

\begin{abstract}
Well developed methods are presently available to help growers meet the demand of the pharmaceutical industry in the next century. Micropropagation of medicinal plants is extensively used to produce active compounds for herbal and pharmaceutical industries. Population growth, urbanization, climate change and unrestricted collection of medicinal plants from nature are resulting in an over- exploitation as well as habit destruction of wild resources of medicinal plants. Conservation of genetic materials of many vulnerable medicinal plants also involves culturing techniques. Micropropagation protocols have been developed for a wide range of medicinal plants, which includes endangered and vulnerable plant species. This review only describes the role of in vitro propagation techniques in medicinal plants.
\end{abstract}

Keywords: Genetic evaluation, medicinal plants, micropropagation

\section{Introduction}

Plants are an important source of medicine and have been the subject of man's curiosity and purposive since time the immemorial. Herbal medicines are still the mainstay of about $75-80 \%$ of the world population, for primary health care because of better acceptability with the human body and less side effects (Kamboj, 2000). Medicinal plants provide meaningful inputs for drugs. Their loss through extinction could lead to considerable loss to the society. The Ayurveda system of medicine was taught in ancient universities in India, established as early as 700 B.C. (Takshila) and 500 B.C. (Nalanda). Ayurveda is believed to have matured between 2,500 and 500 B.C. and is deeply rooted in the Indian culture. During the medieval period, it suffered first because of the Mughals and then the British who patronized their own systems of medicine. However, it survived because of its inherent strength, cultural support and use by common people. Medicine and surgery are two welldeveloped branches of the Ayurvedic system of medicine. The specialization branches of modern medicine have similar counterparts in Ayurveda, which reflects the completeness of the system. There are over 2,000 medicinal plants used in the Ayurvedic medicine system (Rout et al., 2000).

The demand for medicinal plant-based raw materials is growing at the rate of 15 to $25 \%$ annually, and according to an estimate of WHO, the demand for medicinal plants is likely to increase more than US \$5 trillion in 2050. In India, the medicinal plant related trade is estimated to be approximately US \$1 billion per year (WHO, 2002; Joshi and Dhawan, 2007). According to an estimate, the quantity of export of Ayurvedic products produced in India has tripled between last two financial years. India has already established a reputation as a low-cost manufacturer of high quality generic drugs in the global market (Kala, 2005). It is expected that India's aim to build a golden triangle between traditional medicine, modern medicine, and modern science will be a boon for developing the traditional herbal medicine and the medicinal plants sector (Ahuja and Ramawat, 2014). Due to climatic and cultural restrictions most medicinal plants are still collected from the wild population or their natural habits. Therefore, increasing of global demand for medicinal plants has resulted in their over- exploitation from their natural habitat (Schippman et al., 2002).

To cope up with this alarming situation, it is very essential to go for immediate conservation of these important plant species through biotechnological approach like plant tissue culture technique (Hassan, 2012). Tissue culture techniques offer a viable tool for mass multiplication and germplasm conservation of elite medicinal plants, while at the same time facilitating pharmaceutical and other commercial needs (Sahoo and Chand, 1998; Anis and Faisal, 2005). Genetic improvement is another approach to augment the drug yielding capacity of the plant (Tejavathi and Shailaja, 1999). 
Plant tissue culture technologies in this context are seen as a savior in channelizing the resources of nature for the benefit of mankind by conservation of elite, endangered plants and eco- friendly production of drugs. The application of tissue culture and rapid propagation methods in different countries become more widespread in both developed and developing countries (Husain and Anis, 2009; Kapi et al., 2010).

Micropropagation is affected by many factors such as explants type, culture medium composition, plant growth regulators (PGRs), selection of explants (elite genotype) and continuous supply of medicinal plants (Gantait and Vahedi, 2015). Martin et al. (2003) reported the highest multiplication rate for $S$. calendulacea of 30 shoots per explants that was obtained after $40 \mathrm{~d}$ of culture after using BAP and $\mathrm{Kn}$.

During the last few years the interest in mass propagation of medicinal plants in vitro has distinctly increased for various reasons. Many of these plants, when propagated by conventional methods, take long time for multiplication, have a low rate of fruit set, poor seed germination and are often under protection or threatened with extinction. The alternative to this situation is the rapid in vitro multiplication of plants and their cultivation under special conditions (Amoo et al., 2009). The application of micropropagation techniques for medicinal plants gives many benefits to the breeders as it enables:

a. Increase in the propagation rate of plants;

b. Rapid multiplication of those plants which in a particular climate do not produce seeds or whose seeds have a low germination capacity;

c. Availability of plants throughout the year, i.e., in all the seasons;

d. Resistance of plants to insects, diseases, and herbicides;

e. Uniform plants of a selected genotype;

f. Production of uniform clones from highly heterozygous plants;

g. Production of plants with changed genotype (tetraploids, haploids, hybrids);

h. Conservation of genetic resources of species and threatened plants;

i. Plant improvement by regeneration technique in conjunction with in vitro cell manipulation.

\section{Importance of Medicinal Plants}

Herbs are staging a comeback and herbal renaissance is happening all over the globe. The herbal products today symbolize safety in contrast to the synthetics that are regarded as unsafe to human and environment. Although herbs had been priced for their medicinal, flavouring and aromatic qualities for centuries, the. However, the blind dependence on synthetics is over and people are returning to the naturals with hope of safety and security. Over three- quarters of the world population relies mainly on plants and plant extracts for health care. More than $30 \%$ of the entire plant species, at one time or other was used for medicinal purposes. It is estimated that world market for plant derived drugs may account for about Rs. 2,00,000 crores. The annual production of medicinal and aromatic plant's raw material is worth about Rs. 200 crores. Various international organization such as the Food and Agriculture Organization (FAO), the United Nations Industrial Development Organization (UNIDO), the World Health Organization (WHO), the International Development Research Centre (IDRC) and others have been addressing issues concerning medicinal and aromatic plants through support for research, networking and coordination (Sharma and Kumar, 2013).

About 8,000 herbal remedies have been codified in Ayurveda. The Rigveda (5000BC) has recorded 67 medicinal plants, Yajurveda 81 species, Atharvaveda (4500-2500 BC) 290 species, Charak-Samhita (700 BC) and Sushrut-Samhita (200 BC) had described properties and uses of 1100 and 1270 species, respectively. Unfortunately, much of the ancient knowledge and many valuable plants are being lost at an alarming rate. With the rapid depletion of forests, impairing the availability of raw drugs, Ayurveda, like other systems of herbal medicines has reached a very critical phase. The red Data Book of India has 427 entries of endangered species of which 28 are considered extinct, 124 endangered, 81 vulnerable, 100 rare and 34 insufficiently known species.

The International Centre for Science and High Technology (ICS-UNIDO) has prepared the Compendium of Medicinal and Aromatic Plants of Asia to present the status of medicinal and aromatic plants of Asian countries. Particularly, herbal drugs are important by several countries for their usage of traditional medicinal preparation from various parts of the country.

Percentage of herbal drugs imported by various countries for drugs preparation

\begin{tabular}{lc}
\hline Country & Percentage of herbal drugs imported \\
\hline China & $45.0 \%$ \\
USA & $15.6 \%$ \\
Australia & $10.5 \%$ \\
India & $3.7 \%$ \\
South Korea & $1.4 \%$ \\
Taiwan & $1.7 \%$ \\
Indonesia & $8.1 \%$ \\
\hline
\end{tabular}

Source: Plant Conservation Biotechnology, edited by Erica E. Benson

The basic requirements for gaining entry into developed countries include well documented traditional use; single plant medicines; medicinal plants free from pesticides, heavy metals etc.; standardization based on chemical and activity 
profile and safety and stability. Important medicinal plants and their parts used for the preparation in indigenous system of Indian medicines are reported.

The number of plant species which have at one time or another been used in some culture for medicinal purposes can only be estimated. An enumeration of the WHO from the late 1970s listed 21000 medicinal species. However, in China alone 4941 of 26092 native species are used as drugs in Chinese traditional medicine, an astonishing 18.9 percent. If this proportion is calculated for other well- known medicinal floras and then applied to the global total of 422000 flowering plant species, it can be estimated that the number of plant species used for medicinal purpose is more than 50000 .

\begin{tabular}{lccc}
\hline \multicolumn{3}{l}{ Medicinally used plants } & \\
\hline Country & $\begin{array}{c}\text { Plant } \\
\text { species }\end{array}$ & $\begin{array}{c}\text { Medicinal } \\
\text { plant species }\end{array}$ & $\begin{array}{c}\text { Percentage } \\
\text { (\%) }\end{array}$ \\
\hline China & 26092 & 4941 & 18.9 \\
India & 15000 & 3000 & 20.0 \\
Indonesia & 22500 & 1000 & 4.4 \\
Malaysia & 15500 & 1200 & 7.7 \\
Nepal & 6973 & 700 & 10.0 \\
Pakistan & 4950 & 300 & 6.1 \\
Philippines & 8931 & 850 & 9.5 \\
Srilanka & 3314 & 550 & 16.6 \\
Thailand & 11625 & 1800 & 15.5 \\
USA & 21641 & 2564 & 11.8 \\
Viet Nam & 10500 & 1800 & 17.1 \\
Average & 13366 & 1700 & 12.5 \\
World & 422000 & 52885 & \\
\hline
\end{tabular}

Source: Biotechnology and Biodiversity, edited by Ahuja and Ramawat

There is a vast, secretive, and largely unregulated trade in medicinal plants, mainly from the wild which continue to grow dramatically in the absence of serious policy attention with environmental planning (Saikia and Handique, 2014). In general, the demand for medicinal plants and herbal remedies and especially its renaissance in the developed countries is driven by the following factors-

$>$ Increasing costs of institutional, pharmaceutical- based health care.

$>$ Interest of individuals, communities and national governments in greater self- reliance in health care.

$>$ Interest of individuals, communities and national governments in small and large-scale industrial development based on local/ national biodiversity resources.

$>$ Increasing success in validating the safety and efficacy of herbal remedies.
$>$ Legislation improving the status of herbal medicine industry.

$>$ Renewed interest of companies in isolating useful compounds from plants.

$>$ Search for new drugs and treatments of serious and drugresistant diseases.

$>$ Marketing strategies by the companies dealing in herbal medicine.

There is no reliable figure for the total number of medicinal plants on Earth, and numbers and percentages for countries and regions vary greatly. Estimates for the numbers of species used medicinally include: $35000-70000$ or 53000 worldwide; 10000-11250 in China; 7500 in India; 2237 in Mexico and 2572 traditionally by North American Indians. The great majority of species of medicinal plants are used only in Folk Medicine. Traditional Medical Systems employ relatively few: 500-600 commonly in Traditional Chinese Medicine (but 6000 overall); 1430 in Mongolian Medicine; 1106-3600 in Tibetan Medicine; 1250-1400 in Ayurveda; 342 in Unani; and 328 in Siddha (Schippmann, 2001).

Numbers and percentages of medicinal plant species recorded for different countries and regions

\begin{tabular}{lccc}
\hline $\begin{array}{l}\text { Country or } \\
\text { region }\end{array}$ & $\begin{array}{c}\text { No. of species } \\
\text { of medicinal } \\
\text { plants }\end{array}$ & $\begin{array}{c}\text { Total no. of } \\
\text { native species } \\
\text { in flora }\end{array}$ & $\begin{array}{c}\text { \% of flora } \\
\text { which is } \\
\text { medicinal }\end{array}$ \\
\hline China & 11146 & 27100 & 41 \\
India & 7500 & 17000 & 44 \\
Mexico & 2237 & 30000 & 7 \\
North America & 2572 & 20000 & 13 \\
World & 52885 & $297000-$ & $10-18$ \\
& & 510000 & \\
\hline
\end{tabular}

Source: Biotechnology and Biodiversity, edited by Ahuja and Ramawat

\section{Micropropagation and its Advantages}

Micropropagation derives its name from the miniatures shoots/ plantlets initially produced from this method of plant propagation. This method provides a rapid and reliable system for production of genetically uniform and disease free plantlets. It is one of the important contributions of plant tissue culture to commercial plant propagation and has huge implication (Jha and Ghosh, 2005). Micropropagation is the process of vegetative growth and multiplication from plants tissues and it is encompassing several in vitro aseptic culture techniques that enable parts of a plant to be cultivated artificially on nutrient medium (Leifert et al., 1989). The media are formulated to permit diverse growth patterns including cell multiplication, organ formation and plant regeneration. Micropropagation is based on concept of totipotency; the ability of plant cells and tissues to develop into whole new 
plant (Bhojwani and Razdan, 1996). Gottlieb Haberlandt, a German botanist is considered as the father of plant tissue culture, was the first to separate and culture plant cells on Knop's salt solution in 1898 (Krikorian and Berquam, 1969).

In conventional propagation methods of many plants, seed germinate rate is very poor, flowers and seed producing time under a certain climatic conditions or have long periods of growth and multiplication. For wild growing species, the use of seeds as an initial material should be more suitable because this system allows the conservation of a wide genetic basis (Engelmann, 1997). Micropropagation ensures a continuous supply of medicinal plants, using minimum space and time (Prakash and Van Staden, 2007). Micropropagation has now become a well established technique for culturing and studying the physiological behavior of isolated plant organs, tissues, cells, protoplasts and even cell organelles under precisely controlled physical and chemical conditions (Sharma et al., 2010). The use of in vitro methods to conserve plant material has some advantages compared to the maintenance of living collections in field condition (Engelmann, 1997). The advantages of micropropagation of medicinal plants are-

i. Higher rate of multiplication

ii. Environment can be controlled or altered to meet specific needs of the plant

iii. Absence of the risk of being damaged by insects and diseases

iv. Continuous supply of medicinal plants around the year

v. The possibility of propagation with labored reproduction by seeds

vi. Plant production are independent of regional or seasonal variation

vii. Identification and production of clones with desired characteristics

viii. Elite clone of different important plant species can be maintained

ix. New improved genetically engineered plants can be produced

\begin{tabular}{|c|}
\hline Steps of in vitro propagation \\
\hline Selection of plant materials \\
\hline$\downarrow$ \\
\hline Selection of explants \\
\hline$\downarrow$ \\
\hline Surface disinfection \\
\hline$\downarrow$ \\
\hline $\begin{array}{c}\text { Explants inoculation on to different plant tissue culture } \\
\text { medium with or without PGR for shoot multiplication and } \\
\text { root initiation }\end{array}$ \\
\hline$\downarrow$ \\
\hline Acclimatization \\
\hline$\downarrow$ \\
\hline Evaluation of the genetic stability \\
\hline
\end{tabular}

$x$. Conservation of endangered plant species

$x i$. The possibility of long term conservation or cryopreservation of genetic materials of plants

xii. The requirements of relatively small plots of field

xiii. Production of secondary metabolites

\section{Purpose of Micropropagation}

Plant genetic resources provide basic needs and help solve problems such as hunger and poverty. Plant genetic resources are the most valuable and essential basic raw materials to meet the current and future needs of crop improvement programmes. However, they are being lost, i.e., the genetic erosion due to the result of a number of factors, including habitat fragmentation, over-exploitation (overgrazing and excessive harvesting), competition from exotics (accidental and planned introductions), changes in land use (deforestation and land clearance), population growth, and climate change. The main cause of genetic erosion in the last 40 years has been the spread of modern, commercial agriculture and the replacement of diverse farmer plant varieties with modern, hybrid varieties. The situation warrants acceleration of efforts to develop methods for their germplasm preservation. Given their vital importance, we must conserve them for the benefit of both present and future generations (Gashi et al., 2015).

Advances in plant biotechnology, especially those associated to in vitro culture and molecular biology have also provided powerful tools to support and improve conservation and management of plant diversity. At present, biotechnological methods have been used to conserve endangered, rare ornamental, medicinal and forest species, allowing the conservation of pathogen-free material, elite plants and genetic diversity for short, medium and long-term. Tissue culture systems allow propagating plant material with high multiplication rates in an aseptic environment. Following two alternative morphogenic pathways, shoot organogenesis or somatic embryogenesis, tissue culture has been extensively developed and applied for propagation and regeneration of over 1000 different plant species, including numerous rare and endangered species.

Micropropagation is a method of propagating plants by culturing very small parts and it is the true-to-type propagation of selected genotypes using in vitro culture techniques. Micropropagation derives its name from the miniature shoots/ plantlets initially produced from this method of plant propagation. This technique provides a rapid and reliable system for production of genetically uniform and disease free plantlets and it is one of the important contributions of plant tissue culture to commercial plant propagation and has vast significance. Since the harvest of medicinal plants on a mass scale from their natural habitats is leading to a depletion of plant resources, the conservation of these valuable genotypes is imperative. Micropropagation is an effective approach to conserve such germplasm. Further, genetic improvement is 
another approach to augment drug-yielding capacity of the plant (Tejavathi and Shailaja, 1999).

\section{Evaluation of Micropropagated Plants}

The use of in vitro techniques has a risk of somaclonal variation. It is, therefore, necessary to assess the genetic stability of the cultures, particularly, to fulfill the aim of genetic conservation. A combination of several techniques is recommended for the evaluation of genetic changes of the regenerated plants, but especially evaluated one of the most common technique based on morphological characters of regenerated plants in compare to source plants. Now in modern science, it is included in the studies on chromosome structure and number, or the evaluation of active principle of the regenerated plants. The aim of the in vitro techniques is the genetic conservation, thus justify the need to monitor the stability of in vitro cultured plants at different stages of the process. The analysis of plants regenerated from in vitro conservation procedures can be performed at the phenotypic, cytological, phytochemical analysis. The approaches taken to examine genetic stability in germplasm of in vitro regenerated plants are likely to be dependent on several practical factors such as the size of the germplasm collection, expertise, costs and labour (Harding, 1996). Chromosome studies from tissue culture are perquisites to identify whether the regenerated plants are cytologically true-to-type or are variants (Jha and Ghosh, 2005). The cytological stability of micropropagated plants needs to be checked before using this protocol at the commercial level (Bhojwani and Razdan, 1996; Landey et al., 2015; Regalado et al., 2015; Tomiczak et al., 2015). The position of centromere and the relative chromosome size are the two most important karyotypic features which have allowed reasonable assessment of chromosomal affinities based on the concept of symmetry vs asymmetry.

The phytochemical studies of different medicinally important plant species are surely constrained by the lack of readily available plant materials. Therefore, the development of tissue culture systems is an urgent goal science their availability will foster studies for isolation of the different active compounds of different medicinal plant species which is more important in different pharmaceutical industries. Evaluation of phytochemical content through HPTLC and HPLC techniques are very popular in herbal medicine and pharmaceutical industry due to easy learns and is not limited by the volatility or stability of the sample compound (Dubey et al., 2004). Secondary metabolites represent an immense diversity of molecular structure and biological function. More than $1,00,000$ of them have been discovered from about $15 \%$ of the estimated 5,00,000 plant species. These biologically active molecules are the active principles of most crude plant products, including traditional botanical drugs. The can be extracted from plants and purified for commercial use as medicines, aromatics, hallucinogens, narcotics, poisons, stimulants, etc (Liang et al., 2004).

\begin{tabular}{|c|c|c|c|}
\hline \multicolumn{4}{|c|}{ Medicinal plant species for which micropropagation protocols has been reported } \\
\hline Species & Explants type & Culture media & Author \\
\hline Piper barberi & Nodal segments & $\begin{array}{l}\text { MS media with BAP }\left(1.0 \mathrm{mg} \mathrm{l}^{-1}\right) \& \mathrm{Kn}(0.5 \\
\left.\mathrm{mg} \mathrm{l}^{-1}\right)\end{array}$ & Ananda and Rao, 2000 \\
\hline Plumbago zeylanica & Nodal segment & $\begin{array}{l}\text { MS media with BA }\left(1.0 \mathrm{mg} \mathrm{l}^{-1}\right) \text {, IAA (0.01 } \\
\left.\mathrm{mg} \mathrm{l}^{-1}\right)\end{array}$ & Rout et al., 2001 \\
\hline Gloriosa superba & Root & $\begin{array}{l}\text { MS media with p-coumaric acid (20.0 mg } \\
\left.\left.\mathrm{I}^{-1}\right) \text { \& tyramine }\left(20.0 \mathrm{mg} \mathrm{l}^{-1}\right)\right)\end{array}$ & Ghosh et al., 2002 \\
\hline Rauvolfia micrantha & Young root cuttings & $\begin{array}{l}\text { MS media with } \\
\operatorname{BAP}\left(0.2 \mathrm{mg} \mathrm{l}^{-1}\right) \& \text { NAA }\left(0.1 \mathrm{mg} \mathrm{l}^{-1}\right)\end{array}$ & Sudha and Seeni, 2006 \\
\hline Artemisia vulgaris & Seeds & MS media with BAP $(4.54 \mu \mathrm{M})$ & $\begin{array}{l}\text { Sujatha and Ranjita Kumari, } \\
2007\end{array}$ \\
\hline Tinospora cordifolia & Nodal segment & $\begin{array}{l}\text { MS media with BAP }\left(2.0 \mathrm{mg} \mathrm{l}^{-1}\right) \text { \& NAA } \\
\left(1.0 \mathrm{mg} \mathrm{l}^{-1}\right)\end{array}$ & Tabassum and Nag, 2008 \\
\hline Vanilla planifolia & Nodal segments & $\begin{array}{l}\text { MS media with BAP }\left(1.0 \mathrm{mg} \mathrm{l}^{-1}\right) \& \mathrm{Kn}(1.5 \\
\left.\mathrm{mg} \mathrm{l}^{-1}\right)\end{array}$ & Abebe et al., 2009 \\
\hline Campanula polymorpha & Nodal segments & $\begin{array}{l}\text { MS media with BAP }\left(1.0 \mathrm{mg} \mathrm{l}^{-1}\right) \& \text { NAA } \\
\left(0.1 \mathrm{mg} \mathrm{l}^{-1}\right)\end{array}$ & Paunescu, 2010 \\
\hline Curcuma vamana & $\begin{array}{l}\text { Rhizome nodal seg- } \\
\text { ments }\end{array}$ & MS media with BAP $\left(1.0 \mathrm{mg} \mathrm{l}^{-1}\right)$ & Bejoy et al., 2012 \\
\hline Withania somnifera & Seed & MS media with BAP $\left(1.0 \mathrm{mg} \mathrm{l}^{-1}\right)$ & Pandey et al., 2013 \\
\hline Tashnedari sp. & Shoot tip & $\begin{array}{l}\text { MS media with BAP }\left(2.5 \mathrm{mg} \mathrm{l}^{-1}\right) \& \text { NAA } \\
\left(2.5 \mathrm{mg} \mathrm{l}^{-1}\right)\end{array}$ & Lalabadi et al., 2014 \\
\hline
\end{tabular}




\section{Conclusion}

Plants are wealthy source of pharmaceutical significant compounds. A number of plant species are undiscovered and their medicinal properties are also unidentified. Further research and conservation of all plant species including medicinal plants is needed to conserve natures and natural drugs. Tissue culture technique has been used successfully for rapid multiplication and sustainable use of various medicinal plants for future generations.

\section{References}

Abebe, Z., Mengesha, A., Teressa, A., Tefera, W., 2009. Efficient in vitro multiplication protocol for Vanila planifolia using nodal explants in Ethiopia. African Journal of Biotechnology 8, 6817-6821.

Ahuja, M.R., Ramawat, K.G., 2014. Biotechnology and Biodiversity. Springer International Publishing Switzerland.

Amoo, O.S., Finnie, F.J., Staden, V.J., 2009. In vitro propagation of Huernia hystrix: an endangered medicinal and ornamental succulent. Plant Cell, Tissue and Organ Culture 96, 273-278.

Anand, A., Rao, C.S., 2000. A rapid in vitro propagation protocol for Piper barberi Gamble, a critically endangered plant. In vitro cellular and Developmental Biology- Plant 36, 61-64.

Anis, M., Faisal, M., 2005. In vitro regeneration and mass multiplication of Psoralea corylifolia- an endangered medicinal plant. Indian Journal of Biotechnology 4, 261-264.

Bejoy, M., Mathew, D., Anish, N.P., Anjana, R.G.N., 2012. Micropropagation of an Indian Ginger (Curcuma vamana Sabu and Mangaly)- a wild relative of turmeric. Biotechnology 6, 1.

Bhojwani, S.S., Razdan, M.K., 1996. Plant tissue culture: Theory and Practice, a revised edition. Elsevier Science, The Netherlands, 49-51.

Dubey, N.K., Kumar, R., Tripathi, P., 2004. Global promotion of herbal medicine: India's opportunity. Current science 86, 37-41.

Engelmann, F., 1997. In vitro conservation methods, in Biotechnology and Plant Genetic Resources: conservation and use. B.V. Ford- Lloyd, J.H. Newburry and J.A. Callow (eds), CABI, Wellingford 119-162.

Gantait, S., Vahedi, M., 2015. In vitro regeneration of high value spice Crocus sativus L.: a concise appraisal. Journal of Applied Research on Medicinal and Aromatic Plants 2, 124-133.

Gashi, B., Abdullai, K. Sota, V., Kongjika, E., 2015. Micropropagation and in vitro conservation of the rare and threatened plants Ramonda serbica and Ramonda nathaliae. Physiology Molecular Biology Plants 21, 123-136.
Ghosh, B., Mukherjee, S., Jha, T.B., Jha, S., 2002. Enhanced colchicines production in root cultures of Gloriosa superba by direct and indirect precursors of the biosynthetic pathways. Biotechnology Letters 24, 231-234.

Harding, K., 1996. Approaches to assess the genetic stability of plants recovered from in vitro culture, in Normah M.N. (Ed.), Proceedings of the International Workshop on in vitro Conservation of Plant Resources, 137-170.

Hassan, R.A.B., 2012. Medicinal Plants (Importance and Uses). Pharmaceutica Anal Acta 3, 10.

Husain, M.K., Anis, M., 2009. Rapid in vitro multiplication of Melia azedarach L. (a multipurpose woody tree). Acta Physiology Plant 31, 765-772.

Jha, T.B., Ghosh, B., 2005. Plant tissue culture. Basic and Applied. Universities Press (India) Private Limited.

Joshi, P., Dhawan, V., 2007. Axillary multiplication of Swertia chirayita (Roxb. Ex Fleming) H. Karst., a critically endangered medicinal herb of temperate Himalayas. In Vitro Cell Development Biology- Plant 43, 631-638.

Kala, C.P., 2005. Indigenous uses, population density and conservation of threatened medicinal plants in protected areas of the Indian Himalayas. Conservation Biology 19, 368-378.

Kamboj, V.P., 2000. Herbal medicine. Current Science 78, 35-39.

Kapi, Y.V., Kapoor, P., Rao, U.I., 2010. In vitro propagation for conservation of rare and threatened plants of India- a review. International Journal of Biological Technology 1, 1-14.

Krikorian, A.D., Berquam, D.L., 1969. Plant Cell and Tissue Cultures: the role of Haberlandt. The Botanical Review 35, 59-67.

Lalabadi, M.A., Jelodar N.A.B., Bhagheri, N.A., 2014. Micropropagation of Teshnedari an endangered medicinal plant in vitro culture. Bulletin Environmental Pharmacology and Life Sciences 3, 254-257.

Landey, R.B., Cenci, A., Guyot, R., Bertrand, B., Georget, F., Dechamp, E., Aribi, J.C., Lashermes, P., Etienne H., 2015. Assessment of genetic and epigenetic changes during cell culture ageing and relations with somaclonal variation in Coffea arabica. Plant Cell, Tissue and Organ Culture 122, 517-531.

Leifert, C., Waites, W.M., Nicholas, J.R., 1989. Bacterial contaminants of micropropagated plant cultures. Journal of Applied Microbiology 67, 353-361.

Liang, Y.Z., Xie, P., Chan, K., 2004. Review: quality control of herbal medicines. Journal of Chromatography 812, 53-70.

Martin, K.P., Beena, M.R., Joseph, D., 2003. High frequency axillary bud multiplication and ex vitro rooting Wedelia chinensis (Osbeck) Merr. - a medicinal plant. Indian Journal of Experimental Biology 41, 262-266.

Pandey, V., Mishra, M.K., Atri, N., Misra, P., 2013. In vitro 
seed germination of different chemotypes of Withania somnifera. International Journal of Technical Research and Applications 1, 1-6.

Paunescu, A., 2010. In vitro propagation of Campanula polymorpha Witas- an endemic plant of Carpathian mountains. Analele Universitatii din Oradea- Fascicula Biologie XVII, 235-238.

Prakash, S., Van Staden, J., 2007. Micropropagation of Hoslundia opposite Vahl- a valuable medicinal plant. South African Journal of Botany 73, 60-63.

Rout, G., Das, G., Samantaray, S., Das, P., 2001. Micropropagation of Plumbago zeylanica L. by encapsulated nodal plants. Journal of Horticultural Science 76, 24-29.

Rout, G.R., Samantaray, S., Das, P., 2000. In vitro manipulation and propagation of medicinal plants. Biotechnology Advances 18, 91-120.

Sahoo, Y., Chand, P.K., 1998. Micropropagation of Vitex negundo L., a woody aromatic medicinal shrub, through high frequency axillary shoot proliferation. Plant Cell Reports 18, 301-307.

Saikia, M., Handique, P.J., 2014. In vitro propagation of Acalyphaindica Linn.: a medicinally important plant. International Journal of Life Sciences Biotechnology and Pharma Research 3, 86-93.

Schippmann, U., 2001. Medicinal plants significant trade study, German Federal Agency for Nature Conservation, Bonn, Germany.

Schippmann, U., Leaman, D.J., Cunninaham, A.B., 2002. Impact of cultivation and gathering of medicinal plants on biodiversity: global trends and issues. Inter- Department Working Group on Biology Diversity for Food and Agriculture, Good and Agricultural Organization of the United Nations, Rome, Italy.
Sharma, M., Kumar A., 2013. Ethnobotanical uses of medicinal plants: a review. International Journal of Life Science and Pharma Research 3, 52-57.

Sharma, S., Rathi, N., Kamal, B., Pundir, D., Kaur, B., Arya, S., 2010. Conservation of biodiversity of highly important medicinal plants of India through tissue culture technology- a review. Agriculture Biology Journal of North America 1, 827-833.

Sudha, C.G., Seeni, S., 2006. Spontaneous somatic embryogenesis on in vitro root segment cultures of Rauvolfia micrantha Hook F.- a rare medicinal plant. In vitro cellular and Developmental Biology- Plant 42, 119-123.

Sujatha, G., Ranjitha Kumari, B.S., 2007. Effect of phytohormones on micropropagation of Artimesia vulgaris L. Acta Physiologiae Plantarum 29, 189-195.

Tabassum, A., Nag, K.K., 2008. In vitro regeneration of Tinospora cordifolia Miers- a medicinal climbing shrub. Vegetos 21, 125-128.

Tejavathi, D.H., Shailaja, K.S., 1999. Regeneration of plants from the cultures of Bacopa monnieri (L.) Pennell. Phytomorphology 49, 447-452.

Tomiczak, K., Mikula, A., Sliwinska, E. Rybezynski, J.J., 2015. Autotetraploid plant regeneration by indirect somatic embryogenesis from leaf mesophyll protoplasts of diploid Gentiana decumbens L. F. In vitro Cell Developmental Biology Plant 51, 350-359.

WHO., 2002. WHO traditional medicine strategy. World Health Organization, Geneva. 